\section{Production of Pseudomonas Cells Having a High Fumarate Hydratase Activity}

\section{P. ZafFaroni, N. Oddo, R. Olivieri and L. FormICONI \\ Snamprogetti-Laboratorio Processi \\ Microbiologici-Monterotondo, Roma}

Received September 30, 1974

$\mathrm{L}(-)$ Malic acid has found many uses in the food industries as a flavoring and acidulating agent (Irwin et $\left.a l^{1}{ }^{1}\right)$. Our laboratory is engaged in the study of enzymes insolubilized by entrapment into fibres $\left(\right.$ Dinelli $\left.{ }^{21}\right)$. The production of $\mathrm{L}(-)$ malic acid by the enzymic hydration of fumaric acid, catalyzed by fibreentrapped Fumarate Hydratase $(\mathrm{FH})$ was investigated (Mosti et al..$^{3}$ ). In this communication we report on the production of microbial cells having a high $\mathbf{F H}$ activity for the preparation of the enzyme to be entrapped.

\section{Screening for $F H$ producing strains}

Thirty five bacterial strains, which had been isolated from spoiled milk, were cultivated in shaker flasks containing medium M9F/Y.E. having the following composition (g/liter): $\mathrm{Na}_{2} \mathrm{HPO}_{4} \cdot 2 \mathrm{H}_{2} \mathrm{O}, 7.5 ; \mathrm{KH}_{2} \mathrm{PO}_{4}$, $3.0 ; \mathrm{NH}_{4} \mathrm{Cl}, 1.0 ; \mathrm{NaCl} 0.5 ; \mathrm{MgSO}_{4} \cdot 7 \mathrm{H}_{2} \mathrm{O} 0.2$; fumaric acid (neutralized to pH 7.0 with $\mathrm{NaOH}$ ) 10.0 and Yeast Extract, 1.0. The $\mathrm{pH}$ of the medium was adjusted to 7.0 .

The FH activity of the cells was determined according to the method originally proposed by Racker, ${ }^{41}$ based on the increase of the Optical Density at $240 \mathrm{~nm}$, due to transformation of $\mathrm{L}(-)$ malic acid into fumaric acid. The cells were collected by centrifugation, washed with $0.1 \mathrm{M} \mathrm{Na}$ phosphate buffer $\mathrm{pH} 7.4$ and disrupted by sonication at a temperature below $8^{\circ} \mathrm{C}$. The cell-free estracts were kept at $4^{\circ} \mathrm{C}$, since it was found that samples kept at $-20^{\circ} \mathrm{C}$ underwent considerable inactivation. For the assay a $0.1 \mathrm{~m}$ solution of $L_{(-)}$malic acid, neutralized to $\mathrm{pH} 7.4$ with $\mathrm{NaOH}$, was mixed with an equal amount of $0.1 \mathrm{M} \mathrm{Na}$ phosphate buffer $\mathrm{pH}$ 7.4. Three $\mathrm{ml}$ of this mixture were placed in both the sample and reference cuvettes $(1 \mathrm{~cm})$ of a recording double-beam spectrophotometer (Beckman DB-GT) and the reaction was started by the addition of $10 \mu \mathrm{l}$ of the cell-free extract (when more active extracts were obtained later during this study, it was found that dilution with buffer caused inactivation of the enzyme, but that samples could be stabilized by diluting with buffer containing $2.5 \times 10^{-3} \mathrm{M} \mathrm{L}(-)$ malic acid). The increase in optical density (O.D.) was recorded for 2 min: one Racker Unit (RU) of $\mathrm{FH}$ activity was taken as the amount of enzyme that caused, in $1 \mathrm{~min}$ at $25^{\circ} \mathrm{C}$ an increase of 0.001 Absorbance units: the ratio (RU/O.D.) of the activity (RU/ml) to the optical density of the culture was taken as an approximate measure of the specific activity of the cells.

The highest FH activity was found in strain SP 744 , which was identified, on the basis of its morphological and cultural characteristics, as very similar to Pseudomonas taetrolens, from which it differs only in the metabolism of lactose. The strain was maintained by monthly transfers on Nutrient Agar.

\section{Study of the culture medium}

An exponentially growing shake flask culture of strain SP 744 on medium M9F/Y.E. was used as inoculum for some $500 \mathrm{ml}$ shake flasks containing 100 $\mathrm{ml}$ of different media, as indicated in Table $\mathrm{I}$. After

Table I. FH Production by Strain SP 744 in Different Media

\begin{tabular}{|c|c|c|c|c|c|c|}
\hline & \multirow{2}{*}{ Culture medium } & \multicolumn{2}{|c|}{$\mathrm{pH}$} & \multirow{2}{*}{$\begin{array}{c}\text { O.D. } \\
(1: 10)\end{array}$} & \multirow{2}{*}{$\begin{array}{r}\text { Activity } \\
\text { RU } / \mathrm{ml}\end{array}$} & \multirow{2}{*}{$\begin{array}{l}\text { Sp. Act. } \\
\text { RU/O.D. }\end{array}$} \\
\hline & & Initial & Final & & & \\
\hline M9F/Y.E. & & 7.0 & 8.6 & 0.210 & 975 & 387 \\
\hline$"$ & +Trace elements ${ }^{a)}$ & 7.0 & 8.6 & 0.218 & 1,240 & 568 \\
\hline$"$ & $+20 \mathrm{~g} / l$ beet molasses & 7.0 & 8.6 & 0.275 & 1,650 & 600 \\
\hline$"$ & $+10 \mathrm{~g} / \mathrm{l}$ glucose & 7.0 & 6.7 & 0.178 & 850 & 478 \\
\hline$" \prime$ & $+10 \mathrm{~g} / l \mathrm{CSL}^{b /}$ & 7.1 & 8.5 & 0.185 & 1,100 & 595 \\
\hline " & $+5 \mathrm{~g} / l$ peptone & 7.0 & 8.6 & 0.190 & 1,000 & 527 \\
\hline$F 8^{\circ}$ & & 7.0 & 8.5 & 0.265 & 2,825 & 1,068 \\
\hline
\end{tabular}

a) Dworkin et al. ${ }^{5}$,

b) Corn steep liquor was heat-treated as follows: the required quantity of CSL was diluted $1: 3$ with water, the $\mathrm{pH}$ was raised to 7.0 with $20 \% \mathrm{NaOH}$, the suspension was heated under stirring and kept at the boiling point for $10 \mathrm{~min}$. After addition of $5 \% \mathrm{w} / \mathrm{v}$ of Celite, the hot suspension was filtered through a Buchner funnel and the residue washed with water. The filtrate was used.

c) CSL, $50 \mathrm{~g} / l$; fumaric acid, $10 \mathrm{~g} / l$. 
$16 \mathrm{hr}$ of incubation at $25^{\circ} \mathrm{C}$ on a rotary shaker, the cultures were examined for $\mathrm{pH}$, growth (optical density as measured on 1:10 dilutions of the broth) and enzyme activity (expressed as $\mathrm{RU} / \mathrm{ml}$ of culture). Since the most interesting results had been obtained in culture media containing considerable amounts of complex ingredients such as molasses and CSL, their use in culture media for $\mathrm{FH}$ production was further investigated: it was found that on medium F15, containing $50 \mathrm{~g} /$ liter $\mathrm{CSL}$ and $5 \mathrm{~g} / \mathrm{liter}$ fumaric acid or on a medium containing $50 \mathrm{~g} /$ liter CSL and $20 \mathrm{~g} /$ liter molasses (no fumaric acid), activities of the order of $3.200 \mathrm{RU} / \mathrm{ml}$ could be obtained.

Further experiments showed that fumaric acid had no effect on growth and a slight, if any, effect on $\mathrm{FH}$ production: its presence seems however to favour the stability of the enzyme produced. The effect of different combinations of $\mathrm{C}$ and $\mathrm{N}$ sources (fumaric acid, glucose, yeast extract, yeast autolysate, CSL, malt extract, casein hydrolysate, Proflo, Pharmamedia, peptone and Vegedor, a vegetable protein hydrolysate) was then examined: the highest production of $\mathrm{FH}$ was obtained when growing strain SP 774 on medium F16, containing (per liter) $50 \mathrm{~g} \mathrm{CSL}, 10 \mathrm{~g}$ glucose and $5 \mathrm{~g}$ fumaric acid: in shake flasks FH activities of more than $6.000 \mathrm{RU} / \mathrm{ml}$ were obtained.

Effect of some physico-chemical conditions on FH production

The effect of the incubation temperature has been examined: as shown in Table II, at $30^{\circ} \mathrm{C}$ both growth and FH production are strongly inhibited. Experiments in stirred jar fermentors confirmed that the optimum incubation temperature for $\mathrm{FH}$ production is between 25 and $28^{\circ} \mathrm{C}$.

Preliminary experiments in shake flasks, in which the

Table II. Effect of the Incubation Temperature of FH Production

\begin{tabular}{|c|c|c|c|c|c|}
\hline \multicolumn{2}{|c|}{ Incubation temperature, ${ }^{\circ} \mathrm{C}$} & \multirow[b]{2}{*}{$\mathrm{pH}$} & \multirow[b]{2}{*}{ O.D. $(1: 10)$} & \multirow[b]{2}{*}{$\mathrm{RU} / \mathrm{ml}$} & \multirow[b]{2}{*}{ RU/O.D } \\
\hline Pre-culture ${ }^{a /}$ & Production $^{b)}$ & & & & \\
\hline $25^{\circ}$ & $25^{\circ}$ & 8.35 & 0.275 & 3,180 & 1,150 \\
\hline $25^{\circ}$ & $30^{\circ}$ & 8.65 & 0.149 & 950 & 640 \\
\hline $30^{\circ}$ & $25^{\circ}$ & 8.40 & 0.275 & 2,870 & 1,040 \\
\hline $30^{\circ}$ & $30^{\circ}$ & 8.60 & 0.185 & 1,350 & 730 \\
\hline
\end{tabular}

a) Shake flasks with medium M9F/Y.E.

b) Shake flasks with medium F15.

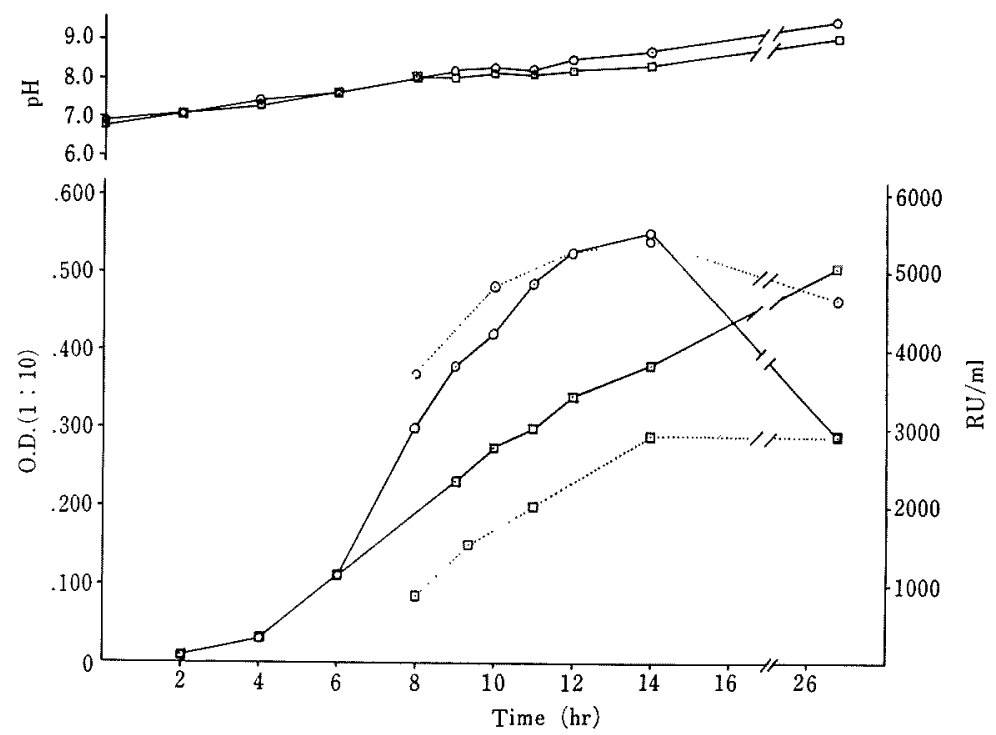

Fig. 1. New Brunswick Jar Fermentors of $7.5 l$ Capacity, Containing $4.5 l$ of Medium F 15 , were Incubated at $28^{\circ} \mathrm{C}$, with an Aeration Rate of $0.5 \mathrm{v} / \mathrm{v} / \mathrm{min}$ and a Stirrer's Speed of 500 and $700 \mathrm{rpm}$. Under the conditions described, the OAR values were 0.25 and $1.70 \mathrm{mM} \mathrm{O}_{2} / / / \mathrm{min}$.

$\odot 500 \mathrm{rpm}(\mathrm{OAR}=0.25) ; \odot 700 \mathrm{rpm}(\mathrm{OAR}=1.70) .-, \mathrm{pH}$ and optically density at $550 \mathrm{~nm}$, measured on $1: 10$ dilution of the culture samples; $\cdots$, enzyme activity (RU/ml). 
aeration, as measured by the Oxygen Absorption Rate (OAR), was varied by using different liquid volumes in $500 \mathrm{ml}$ Erlenmeyer flasks, had shown that at higher OAR values more $\mathrm{FH}$ activity $(\mathrm{RU} / \mathrm{ml})$ could be obtained, but that the cells had a lower specific activity (RU/O.D.). The OAR values ( $\mathrm{mM} \mathrm{O} / / / \mathrm{min})$ were determined by the sulfite oxidation method according to Corman et al. ${ }^{6}$ The effect of the OAR in stirred jar fermentors is illustrated in Fig. 1. It was found in further experiments that it was unnecessary to use conditions which gave OAR values above $1.70 \mathrm{~mm}$ $\mathrm{O}_{2} / l / \mathrm{min}$. During cultivation of strain SP 744 both an synthetic and complex media containing fumarate, the $\mathrm{pH}$ of the culture rises to alkaline values. It was found that preventing the $\mathrm{pH}$ value of the growing culture from rising above 7.0 , by means of automatic $\mathrm{pH}$ control, production of $\mathrm{FH}$ is about $10 \%$ higher as $\mathrm{UR} / \mathrm{ml}$ and even higher as specific activity of the cells (UR/O.D.), since growth was slightly lower under controlled $\mathrm{pH}$ conditions.

\section{REFERENCES}

1) W. E. Irwin, L. B. Lockwood and M. F. Zienty in Kirk-Othmer, "Encyclopedia of Chemical Technology," 2nd edition, Vol. 12, 1967, p. 837 849.

2) D. Dinelli, "Process Biochemistry," Aug. 1972, p. $9 \sim 12$.

3) R. Mosti, W. Marconi and F. Morisi, Communication presented at the FEBS Special Meeting Dublin, 15 19 April, 1973.

4) E. Racker, Biochim. Biophys. Acta, 4, 211 (1960).

5) D. Dworkin and J. W. Foster, J. Bact., 72, 646 (1956).

6) J. Corman, H. M. Tsuchiya, H. J. Koepsell, R. G. Benedict, S. E. Kelley, V. H. Feger, R. G. Dworschack and R. W. Jackson, Appl. Microbiol., 5, 313 (1957). 